\title{
カレント誌の特集記事 綜説などの目録について
}

\author{
——昭和大学図書館の実際——
}

要

約

既成の二次資料が多く出版され，一方ではコンピュータ 一による情報検索が開発されつつある医学㘠書館界にあ って，なおかつ自館で雑誌記事の目録を作成することに ついては，それなりの目的や意義があります。その目的 と意義にはどのような点があるか，また件名を付けるに ついて考慮すべき点はどのようなことであるかを挙げ， 最後に利用の問題点と今後の課題について当館の実際を 中心に考えてみました。

\section{I はじめに}

図書館のすべての仕事が終局的に達するのは, レファ レンス・ワークであるとの考方方が定着して久しい現在 においては，ぞこの図書館でも，それぞれ自館の事情に 即したサービスの方法を日頃から検討，実施していると 思われます。また “医学図書館”誌上にも再三にわたり 種々な方面からこの点につき論じられてきましたが，以 下，標題の点につき，当図畫館のこれまでの経過と現状 及び実際に件名を付する際の留意点, 使用に際しての問 題点と将来どらあるべきかについて考兄てみました。

\section{II 当館の経 過}

私共の図書館でカレント誌の特集記事及び綜説などの 件名（カード）目録を作成するようになったのは，昭和 38 年以来で, そもそもの動機は, 我々館員が利用者から 「○○について書いた新しい本がないか」との質問に対 し，適当な単行書が見当らない時の手持ちの資料として 用意していたもので，選択する論文の内容も件名も利用

* Sachiko SORIMACHI, 昭和大学図曺館
反 町 幸 子*

者に抢ける日頃から質問度の高い主題が中心でした。そ の後，半年ほぞ経過して，ある程度カードも集まり，何 らかの方法でこれらを有効に利用したいと考劣ていた時 に，昭和医学会雑誌（以下，昭和医誌）の編集部より, 毎月，図書館関係の新しい情報を载せたらどうかという 話があり，良い機会でもありましたので，昭和医誌 23 巻 6 号（昭 38 年 9 月）より「図書館月報」と題し，增加 図畫目録や利用統計，図書館案内などと共に「雑誌特集 記事目録」として記载することになりました。それまで の需要があった時の用意のために，と言った消極的なも のから，広く利用者に働きかけるサービスになり，カー ドも利用者が自由に閲覽出来るよう，図書目録カードヶ 一スの一部に「雑誌件名目録」として和洋別々にファイ ルしました。当初は和雑誌の特集と綜説が中心でありま したが，洋雑誌についての Suppl. や綜説も含むように なり, 他に Symposium, 展望, 学会の宿題報告, その 他，適宜必要と思われる論文をも選択の対象とすると共 に, 1965 年からは症候群についての諭文も加えられまし た。その頃の件名は和雑誌は和文の, 洋雑誌については 欧文の件名を付け，ファイルも別にしており，件名の付 け方，ファイルの仕方は，医学中央雑誌の考方方に準じ ておりました。この昭和医誌の月報による情報から，雑 誌を借りに来る利用者も増え，除々にこのような図書館 の仕事が利用者に理解されて来た折に，編集部の都合で 止むを得ず， 28 卷 6 号（昭 43 年 6 月）にて揭載中止と なったことは色々な意味で，非常に残念でした。昭和医 誌の編集は昭和医学会で行なっており, 図書館で発行す る館報とは異なり，発行をでの時間的遅れを生じ，速報 性の点で問題となっていました。そこで，この点を考虑 し，以後は毎週特集記事，Suppl. 綜説だけを一覧にし 
て雑誌閲覧室に揭示する方法をとってみましたが来館者 以外の利用者に対する便宜を計らなかったこともあっ て，その効果は余りなく，これも半年ほどで中止してし まいました。このような利用方法における経緯はありま したが，その間，カードのファイルの方はずっと続けて おり，現在では新着受入れの単行書をも含めて件名目録 だけを独立させ，カードケースを置く場所むカウンター , カレント雑誌架, 雑誌書庫, 二次資料閲覧室のぞこか らも便利な場所を選び利用の便を計っています。そして 和洋雑誌・単行書を一本にまとめてファイルし, 件名む Medical Subject Headings (MeSH) を基本として必要 に応じ，自館に適したように変化させて使用していま す。和書 (誌) の件名に $\mathrm{MeSH}$ を参考とすることに多 少の問題はありましたが，敢えて行なった理由として， まず第一に，今後ますます Index Medicus の利用は多 くなり,これを有効に検索するためには $\mathrm{MeSH}$ の構成 を良く理解していることが重要な要素となり，そのため には日頃から使い慣れていることが最良の方法であるこ と，第二に和洋を別々にファイルしておくと，とかく和 文の諭文のみで利用の要求を満たしてしまう傾向があ り，せっかくの欧文論文が余り利用されない点などで， これらは利用者を含めて, 眓書館員教育の一環にもなる と考えました。第三に $\mathrm{MeSH}$ は内容的にも構成のう党 からも一貫性があり, 字順か語順かで常に問題となるフ アイルの点でもこれに準じれば都合のよいことなどが主 な理由です。

\section{III 目的と意義}

何事につけても事を始めるに当って，その目的と意義 をはっきりと自覚したらえで行なわなければ効果的な結 果は望めません。そこで次に自館で雅誌記事件名目録を 作成することの意義につき考えてみました。

\section{III-(1) 単行書の補助的役割}

そもそも私共の図書館でカレント誌の記事目録を作成 するようになった動機は，近年商業誌（和）において， その編集に「○○特集」と題し，ある主題を取り上げ， それにつき種々の関連領域から，綜合的に捉える目的の 記事に，かなりの頁をさく傾向が現われ，科学雑誌論文 というものが，単にごく細分化された主題について，そ れを必要とする, ある程度限られた読者を対象として書 かれた論文である，との概念ばかりでなく，その時点に おけるその主題概念の総括で, 比較的広範囲の読者を対 象とした，言わば単行書的要素をも含んでいるために，
例总ば利用者が必要とする単行書が自館で所藏していな かったり，所蔵していても貸出中である場合とか「先天 性代謝疾患について」と言ったように必要とする主題に ついてそれだけををとめた単行書がない場合，また，近 年の分子生物学領域の上らに, 新らしい考え方が次々と 出る分野で, 単行書として発行されるまでには理論化さ れていないが，その時点での“をとめ”が必要な場合な ぞに，雑誌の特集が大いに参考になります。

III-（2）学内研究テーマに関する資料の収集

今日, コンピューターによる機械検索が発達し, 実用 化の問題が図書館界やドキュメンテーションの分野で, さかんに論じられ，その方面での先進国である米国では すでに実用化の段階に入り可成りの効果を上げている が，いまだ一般化されるまでには種々の問題があると聞 きます。しかし，ようやく昨年から実験段階に入ったば かりの日本においては，まだまだ解決しなければならな いことが多く，一般の利用者がコンピューターを使用し て検索するようになるのは当分先のように思われます。 一方，より細分化され，利用に便利なように考えて出版 される索引誌や抄録誌はますます增える傾向にあり，そ れらが重要な情報検索のッールであることには異論はあ りませんが，実際問題として，それらを使用し，膨大な 資料の中から，本当に利用者が必要とする論文を手にす るまでには，それぞれのッールの性質を十分理解したう えで検索しても，その図書館での所蔵の有無や資料到着 の有無も関係して，大変な時間と労力が掛かります。そ の点自館所蔵の資料の中から学内研究テーマを十分理解 し，必要とする論文の内容なり，形式なりを知った図書 館員が選択したものは直ぐに役立ち, 多くの諭文が得ら れないをでもそれなりの意義はあります。

III-(3) 学生の学習の参考に

雑誌によっては「補習講座」とか「ジニニア・コー ス」と題して学生や専門外の研究者向きに判りやすく解 説されたシリーズが揭載されることも多く, 学生の学習 やレポート作成の際の参考書として役立ちます。

III-(4) 特集, 增刊号の誌名別目録

カウンター業務で扱う quick referenceによく聞かれ る質問として「2〜3 年前の “○○雑誌”に『心臟弁膜 症』についての特集があり，その中の論文を見たいので すが……と言う場合があります。この際に「心藏弁膜 症」の件名を探すよりは，誌名で見た方が早い点を考 え，誌名別特集記事目録む併せて作成すると便利です。 以上の点が考兄られますが，ある程度利用目的をはっ 
さりさせたらえで雑誌論文を選択すれば，自ずからその 目的に合った件名の与え方が決まり，件名作業もむずか しいものと考党ずに済みます。例光ば（1）の目的には 特集, 綜説, 増刊号などがあり, これらの件名を与劣る 時は, 余り Specific なものよりは一般的なものを, ま た同じ特集でもその中の個々の論文を取り上げたものや Symposium 宿題報告などは（2）の目的になり，件名 はその研究内容に適ったものをと言うことになりなす。

（3）の場合, 学生の質問傾向は拉よそ決っており, だの ような内容を必要とするかは, ある程度カウンタ一業務 を経験しているらちに自ずから摑めるようになります。 カウンター業務には単に貸出しや返却の業務ばかりでな く利用者の質問の内容や，アプローチの仕方にも注意を 向け，それを次の仕事にいかに活用したら良いかを考劣 る事も含むわけです。まして参考係としてそれ専門に携 わる人員を置く余裕のない少人数の図畫館にあっては, 館員全員が参考係であるとの自覚が必要です。当図書館 では全館員が隔離した事務室でなく，常に閲覧者と接す るカウンター内で仕事をしている関係上, 専任の貸出係 ばかりでなく受入係, 目録係, 相互貸借係など誰もがカ ウンター業務をせざるを得ず, 当然のことながら参考質 問にも回答しなくてはなりません。その為には日頃から 雑誌論文や新着書の情報を, 多くの館員が知っておく必 要があるとの溚えにより，カレント誌の件名目録につい ても，雑誌到着と同時に主任司書が必要論文の選択を し，チェックしておいたものを和洋それぞれの受入係が 内容を見ながら論文の件名を与えます。そしてそれらの カードを再び主任司書の処へ集め, 単行書の件名カード をも含め, 件名付けに誴りがないか，上り的確な件名が ないかをチェックしたらえ，全部を貸出係に迴します。 貸出係のところでは件名の統一を計るために, 同じ主題 のものが別の件名になっていないかなどのチェックをし て閲覧用カードボックスにファイルするという方法をと っています。

\section{IV 件名作業と留意点}

件名作業をするに当りまず基本となることは，基礎的 医学知識を得ること，常に医学の動向に目を向けている ことがあげられ，そのためには自分に適した参考書や雑 誌を選び, 目を通すことで, 例えば「からだの科学」「メ ディテーナ」「日本医事新報」「日本医師会雑誌」「話題の 医学」などは解説的な内容が多く，医学図書館員が日頃 から目を通す雑誌として適当であると思います。また各
製薬会社で発行の「治療薬報」「医人薬人」「実験治療」 「武田薬報」などには身体や疾病のしくみを図解したり 短い解説を付けた記事が多く用語の解説書的な利用の仕 方で目を通すのも良いと考岳すす。次に大事なことは， 標題だけでなく論文の要旨を読んでから件名を与えるよ ら心掛けることで，そうすることにより最も内容に相応 しい件名付汁が出来ると共に実際に検索する際にも役立 つことになります。例えば論題が「心臟病について」と なっていても内容が 心臟動脈瘤である場合 HEART DISEASES よりも HEART ANEURYSM ひしくは単 にANEURYSM とした方がより適切な件名となりま す。以下具体的な個々の問題点, 留意点を 2,3 挙げて みました。

IV-(i) 件名の網羅性と特殊性

Index Medicus などのように，莫大な文献量と不特 定多数の利用者を対象とするものは，その索引づけの根 本方針も，自ずからある主題，概念を出来る限り明確に 表わす件名種目を使用することになりますが，文献量や 利用対象の限られた自館の目録の場合には, MeSH にあ るからと言って余り特殊な件名を付けたり，むやみに副 件名を付けると煩雑であるばかりでなく，いざ検索をす る時にとの件名が思いつかず利用されないままになった り，見つかったとしても諭文数が一点といらケースにも なりかねません。反面余り上位概念では論文数の割合に は，必要とするものが少ないといらケースになるので論 文の内容, 主題論文の量, 利用対象などを考慮し, 自館 専用のものであるということを念頭に, 最も利用され得 る件名を選ぶことが必要です。

IV-(ii) Poisoning 副作用と公害病

今日，政治社会問題として注目され，連日マスコミを 賑わしている公害（病）については，当然ながら我々の 扱う雑誌上にも, '大気污染, 水質污濁, 水俣病, イタイ イタイ病, SMON 病, それに最近では佐久の眼病など, これら公害病を含めた中毒関係の論文もかなりの量にな っています。

一口に中毒と言ってもその中にはアルコール中毒, 食 中毒, Co 中毒, 薬剈中毒 (農薬, サリドマイド, キ) ホルムなどの副作用によるもの), 重金属中毒（砒素, 鉛, 水銀, 亜鉛など) 及び有機溶剤中毒 (ベンゼン, ト リクロールエチレン: 塗装・メッキの前処理や機械の蒸 気洗浄に用いられる）があり MeSH にも ABNORMALITIES, DRUG-INDUCED; ALCOHOLIC INTOXICATION; ARGYRIA; BITES AND STINGS; 
CARBON MONOXIDE POISONING; CARBON TETRACHLORIDE POISONING; DERMATITIS MEDICAMENTOSA; FLUORIDE POISONING; FOOD POISONING; GAS POISONING ; HEPAT. ITIS, TOXIC; INERT GAS NARCOSIS; LEAD POISONING; MERCURY POISONING; PLANT POISONING ; PSYCHOSES, TOXIC; SHOCK. TO-

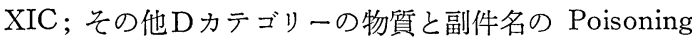
を組み合せれば CADMIUM-Poisoning；BENZENEPoisoning ZINC-Poisoning とすることも出来ますが実 際に利用者が水俣病や佐久の眼病について検索する時に MERCURY POISONING; PHOSPHORUS-Poisoning を探す人はまれで，たいていはその通称名か，その症状 から CENTRAL NERVOUS SYSTEM DISEASES; NEUROLOGIC MANIFESTATIONS ; PERIFERAL NERVE DISEASES あるいは単にPOISONING を見 ると思われます。しかし同じ中毒でも食中毒, サリドマ イド奇形などは, POISONING よりはむしろ CARBON MONOXIDE POISONING, FOOD POISONING; ABNORMALITIES, DRUG-INDUCE を探すと思わ れます。そこで中毒関係の諭文の件名には，一括して Poisoning の処に集め，その中を個々の中毒名別に分け る方法，(2最初から独立した個々の中毒名を件名とする 方法，(3)それぞれの中毒の性質から利用者のアプローチ の仕方を考虑したう点 Poisoning に集めるか個々の中毒 名を件名するかを決める方法とがあり，ぞの方法をとる かは図書館の事情や館員の考方方により，異なると思い ますが，当館では(1)の方法をとって拈り必要に応じ個々 の中毒名から参照カードを入れてます。但しスモン病に ついては現在のところ，整腸剤であるキノホルムによる 副作用との説が注ぼ一致した意見ですが POISONING(SMON) とするよりは独立させて SMON とした方が 色々な意味で良いと思われるので，例外的にこの件名を 使ってます。ところで，公害全般にわたる内容の論文の 場合, 例えば「公害」“産婦の世界” 23(4)：349 388, 71 はその内容が大気污染, 呼吸器疾患, 水質污濁, 農 薬公害, 騒音, 食品添加物と種々な領域に関係し，ぞの 件名を付けたら良いか迷います。公害に相当する用語と してWHO では Environmental Pollution を使い，他 の機関では Environmental Destruction, Environmental Deterioration などを使っていますが $\mathrm{MeSH}$ にはこれら の件名はなく，医学分野で扱う公害とは，内容が主に 公害の人体に及洁す影響を述べたものなので，当館では
ENVIRONMENTAL HEALTH-(Pollution) としてい ます。このように MeSH をそっくりそのまま使うので なく，あくまでもそれを基本にした方法をとっていま す。また公害病の特徵として最初はその原因が判らない ために一定の疾病として診断されず他のものとして扱わ れたり，また特定の疾病として十分理解されない形で報 告されるために, 症状を主としたもの, 疫学的なものが 多く, 従って件名も内科学(神経), 病理解剖, 衛生など の分野にわたっております。その後「水俣病」「イタイイ タイ病」といら統一した名称で呼ばれるようになると諭 題もその名称を符したものが多くなり，次いで原因が究 明されると有機水銀やカドミウムの中毒として論じられ るといった具合で，件名もそれぞれに変化してきます。 いわゆる佐久の眼病と言われて, 昭和 45 年頃より長野 県佐久地方で集団発生をみた視力障害を主症状とする公 害病について子，最初は眼病として眼科や，それが農村 に多いことから職業病の分野に出ていましたが，現在で はその原因が農薬である有機リン（カルバメート郕）で あるとの説により公害病の論文にも多く現われるように なりました。しかし一方では信大，加藤教授が有機リン 農薬中毒とは言えないとの意見もあり，このような場合 にぞの件名標目を与えるか問題となります。公害病の場 合，ある程度マスコミで騒がれてから，その通称名のも とに，そもそものきっかけの頃から，現在をでの論文を 要求してくるケースが多くあります。そこでこの点につ いては, ある程度学界での意見がまとまった時点で, 過 去に発表された論文をる含めて，以後自館で統一した件 名のもとに置けばよく，要はその時期が問題となり，そ のためにも日頃から関係誌や新聞の記事に注意を向けて いることが必要となります。

IV-(3) Child, Infant および Infant, newborn

小児，乳児，新生児の分野では同じ疾患でも成人のそ れとは異なった独特の症状，治療法，手術の方法があ り，成人とは別に論じられ，近頃では小児科系の雑誌ばか りでなく他の雑誌にも多く見られるよらになりました。 かつて内科学から小児科学が独立したように小児科学に 扮いても小児内科，小児外科，小児神経科之独立化への 傾向が現われ，さらには小児血液学，小児内分泌学…… といった細分化の方向もあり，当然利用者の質問にもと のような観点からの需要が增えてきました。Index Medicus に拈いて，それらにつき検索する際は，それぞれ の疾患や生理機序の下を探すことになっていますが，実 際に「小児の (気管支) 喘息について」という場合に喘 
息の件名標目の中から小児についてのみ拾らには，多 少とも時間的むだを禁じ得ず，ぞうして副件名の中に Child や Infant などを加えないのか疑問に思っており ます。もっとも MeSH の中にも DIABETES MELLITUS, JUVENILE の如き標目はありますが....... とも あれ当館ではこれらの点についてはASTHMA-(Child) のように副件名的な使い方をしています。

以上件名を付ける際の問題点, 留意点を挙げてきまし たが, 要するにシソーラスの性格として, 固定したもの, 絶対的なものなどあり得るはずはなく, 学問の進歩, 変 化や索引者の考方方に順応してゆくべきものです。あら ゆる件名標目が，一次資料と利用者の要求とをマッチさ せる手がかりに過ぎず，本来の目的が資料を利用させる ことにあり，件名を与えることが全てではないと考光る と，余り件名づけに気をとらわれ過ぎない方が賢明で， むしろ件名とはそういう性格であることを念頭に，検索 の際，そのような主題概念の展開の仕方をすべきである と考光ます。加件名の “一貫性”については失って はならず自館での考方方をはっきり決めてから件名づけ をすべきで，その時々であちこちに入れることのないよ らにすべきことはいらまでもありません。

\section{V 利用亡今後の問題}

利用に当たり考えなくてはならないことは，まず自館 の雑誌記事目録はあくまでも全資料のほんの一部に過ぎ ず，また，件名についても先に述べたように絶対的なも のでないことを利用者に十分理解してもらい，ある件名 で見当らなくても同義語や主題概念を広げたり，せばめ たりして探すと共にそれでも見当らない時は既成の二次 資料を見ることを奨める必要があります。また当館のよ らに全ての論文に欧文の件名を与えている処では, 主題 の用語を知らなければ日本語の論文すら見つからないこ とになり，利用者の中にはカードケースを出して見て， それが欧文の件名だと判るとそれだけであきらめてしま ら人, パラパラとめくり面倒くさくなってあきらめてし まう人等があり，そのような光景を見ると，単に資料利 用といら点のみを考学るなら, 和洋とも和文の件名をつ けた方が親切であり利用率も上がると思います。しかし 大学図書館の役割の中に, 学生教育の一端を担ら重要な 使命があることを思うと，学生時代にこそ，二次資料及 び文献検索方法についての基礎知識を身につけ, 彼等の 将来の研究に役立つよう学問研究の態度や方法を学ぶこ とも必要と思います。確かに判らないことは館員に尋ね
れば回答が得られ，必要とする文献も依頼すれば挆して もらえると言らことを一般利用者に知ってもらうのは必 要です。しかしそれも場合によりけりで，資料の使い 方, 文献の調べ方を知っている利用者が文献量や時間の 関係で本人が調べるより専門の館員の方がより適切な資 料が得られるとして依頼するのは良いが，使い方，調べ 方が判らないとか，知っていても面倒だからとの理由で 要求してくる利用者に対しては Reference Service の名 のもとに安易に必要とする文献を提供するのでなく文献 のアプローチの仕方をも指導すべきであると思います。

当館の今後の課題としては内容の充実化は勿椧です が，その利用の面で, 現在は館内のカード目録の及で, さながら利用者の Need を待っている受身の状態です。 今後は積極的に図書館の方から Need を撋むようにしな くてはならないと考兵すす。殊に当館の如く図書館が基 礎系研究室棟の中にあり, 臨床の研究室及び病院から離 れたところに位置する処では, 診寮や研究の場と図書館 が何らかの形でもっと接近させなくては，より多くの資 料利用の効果は望めなく, そのためには学内研究テーマ の情報を教室ごとにまとめて提供したり, かつて昭和医 誌に掲載した如く印刷物にして配布する方法もあります が，いずれも速報性はあっても累積性の点で多少問題が あります。出来得札病院や研究室の主要な場所にカー ドケースを置き図書館内と同様にファイルしておくのも 良いと考光ますが，未だにどのような方法をとるかにつ いては具体化して抢らず，目下考慮中というのが現状で す。

\section{VI おわりに}

既成の二次資料が数多く出版され，一方ではコンピュ ーターによる情報検索が開発されつつある医学図書館に あってなおかか自館で䧴誌記事の目録を作成すること については，それなりの目的や意義があります。その目 的と意義にはどのような点があるか，また，実際に件名 を付けるに当って考慮すべき点，すなわち基礎的専門知 識の修得と科学情報への積極的な関心を持つこと, 論文 の選択や件名標目はあくまでも自館の事情一(1)利用対 象: 教室, 大学院生, 学生, 看護婦, (2)目的: 診療, 論 文作成の準備, 講義用, (3)必要論文の種類 : 原著, 綜説, 議事録, 症例, 統計一に即したものを選択すべきことを 挙げ, 最後に利用の問題点と今後の課題について当館の 実際を中心に考えてみました。 